\title{
Аналіз силових показників висококваліфікованих армспортсменів на етапі передзмагальної підготовки
}

\author{
Ігор Мазуренко
}

Харківська державна академія фрізичної культури, Харків, Україна

\begin{abstract}
Мета: аналіз показників силової підготовки основних змагальних рухів армспортсменів вищої кваліфрікації на етапі передзмагальної підготовки. Завдання роботи: аналіз тренувального процесу при підготовці до змагань з армрестлінгу; виявлення оптимальних силових показників при підготовці до змагань з армрестлінгу; визначення методики підготовки до головних змагань з армрестлінгу.

Матеріал і методи: теоретичнийаналіз іузагальненняданихнауково-методичноїлітературитаметодикитренувального процесу висококваліфікованих армспортсменів при підготовці до основних змагань, педагогічний експеримент (кистьова динамометрія, тензодинамометрія). Матеріал: у процесі дослідження проведено виміри силових показників в основних змагальних рухах висококваліфрікованих 24 армспортменів 3 вагових категоріях (до 80 ке, 80-100 кг, понад 100 кг) по 8 осіб у кожній на етапі передзмагальної підготовки. Показники вимірювали електротензодинамометром серії FBk польського виробництва з класом точності до 100 грамів, за допомогою спеціально виготовленого блочного пристрою «Прибор ARM1».

Результати: в результаті аналізу, визначено, що силові показники 4 змагальних рухів (згинанні пальців, натяжкамолотом, гак, згинанні кисті) висококваліфрікованих армспортсменів були достовірно високими у ваговій категорії 80-100 ке. Причому показник сили гаку правої руки був найвищим саме у цій ваговій групі, а найнижчий показник зафріксовано у ваговій групі до 80 кг у згинанні пальців.

Висновки: порівняльний аналіз усіх досліджених показників силових можливостей висококваліфрікованих армспортсменів дозволив встановити, що найбільш високі результати були показані в силових вправах гак і згинанні кисті; можна стверджувати, що силові вправи дозволяють достатньо чітко визначити рівень силової підготовленості армспортсменів, а сама ие $\epsilon$ головним показником результативності висококваліфрікованих армспортсменів; отримані результати свідчать про те, що армспортсмени з гіршими силовими показниками досягають результатів за рахунок включення до виконання силових вправ більшої кількості м'язових груп і, навпаки, більш високі силові показники досягаються за рахунок виконання силових вправ певною м'язовою групою.
\end{abstract}

Ключові слова: армрестлінг, силові показники, змагання, спортсмени.

\section{Bступ}

Підготовка спортсменів високої кваліфікації - головний об’єкт дослідження сучасної науки та спорту, в якій вирішується завдання розробки основ раціональної організації тренувального процесу. Найважливішим елементом такої організації може стати система комплексного контролю рівнів підготовленості спортсменів, що враховує всі чинники, які її формують. У зв'язку з цим виникає потреба точного визначення показників рівняспортивної майстерності армспортсмена, особливо на стадії підготовки до головного старту, тобто етапі передзмагальної спеціалізованої підготовки. Оскільки техніко-тактична підготовка у спортсменів вищої кваліфрікації знаходиться на приблизно однаковому рівні, то особливу увагу необхідно приділяти контролю за силовими показниками.

Вивчення досвіду підготовки та виступу у змаганнях лідерів світового армрестлінгу дає унікальну інформацію, в якій сконцентрований позитивний досвід спортсмена. Проте, до теперішнього часу методичні аспекти побудови індивідуальних тренувальних процесів провідних армрестлерів світу ще не стали об'єктом пильної уваги дослідників. Такі роботи одиничні [3; 4; 11; 12], хоча їх значущість як з теоретичної, так і з практичної точки зоруне викликає сумніву.

3 метою підвищення ефрективності даних програм підготовки сьогодні активно використовуються різнітехнічні засоби, однак, незважаючи на порівняно великукількість сучасних досліджень і розробок в цій галузі [5; 6; 14], нині залишається ряд питань, які потребують подальшоговивчення.

По-перше, недостатньо вивчені адаптаційні реакції організму спортсменів, що займаються армспортом, на фрізичні навантаження з використанням певних груп м'язів верхніх кінцівок, тулуба, а також нижніх кінцівок [14]

По-друге, при використанні спеціальних тренажерних пристроїв не завжди враховуються біомеханічні особливості змагального руху, що призводить до зниження тренувального ефекту як тренованого фрізичного якості, так і ефективності вирішення рухового завдання при виконанні змагальних рухових дій $[7 ; 8]$

По-третє, наявні окремі наукові дані, які дозволяють говорити про те, що при правильному поєднання динамічних і статичних напружень можна отримати більш виражені результати в прирості сили [1; 3; 4]. Але в той же час досліджень, спрямованих на застосування статичних напружень в спортивному тренуванні з метою розвитку сили, проводилося вкраймало.

У зв'язку з цим проблема створення нових, більш ефективних методик підготовки в армспорті, $є$ актуальною, а вивчення тренувальних ефектів, які виникають в процесі підготовки, має практичний інтерес. Армрестлінг має свої особливості побудови тренувального процесу висококваліфікованих спортсменів, заснованого на індивідуалізації тренувальної та змагальної діяльності [3; 15 ; $16]$. 


\section{СЛОБОЖАНСЬКИЙ НАУКОВО-СПОРТИВНИЙ ВІСНИК:}

\section{Матеріали XIX Міжнародної науково-практичної конференції «Фізична культура, спорт і здоров'я: стан, проблеми та}

На сьогоднішній день у процесі підготовки армспортсменів, які мають високі спортивні досягнення, включаючи перемоги на чемпіонатах Європи і світу, накопичений певний обсяг емпіричного матеріалу, що вимагає систематизації та теоретичного осмислення. В цьому плані, безперечно, актуально проаналізувати особливості тренувальної діяльності зармрестлінгу, які показують основні напрямки та особливості індивідуалізації тренувального процесу для досягнення високих спортивних результатів.

Зв'язок роботи 3 науковими програмами. Дослідження виконано в рамках реалізації наукового проекту на 2016-2018 р.р. «Теоретико-методичні основи розвитку неолімпійського спорту» (номер державної реєстрації 0115U002372), а також відповідно до пріоритетного тематичного напряму наукових досліджень ХДАФК «Цільові дослідження з питань «людина - світ» і створення нових технологій поліпшення якості життя» за темою «Моделювання техніко-тактичних дій кваліфікованих спортсменів в плаванні і швидкісно-силових дисциплінах легкої атлетики» (номер державної реєстрації 0111U000191).

Мета роботи - аналіз показників силової підготовки основних змагальних рухів армспортсменів вищої кваліфрікації на етапі передзмагальної підготовки.

Завдання роботи: 1) аналіз тренувального процесу при підготовці до змагань з армрестлінгу; 2) виявлення оптимальних силових показників при підготовці до змагань з армрестлінгу; 3) визначення методики підготовки до головних змагань з армрестлінгу.

\section{Матеріал і методидослідження}

В роботі використовувалися наступні методи до-

слідження: теоретичний аналіз і узагальнення даних науково-методичної літератури та методики тренувального процесу висококваліфікованих армспортсменів при підготовці до основних змагань, педагогічний експеримент (кистьова динамометрія, тензодинамометрія).

Матеріал: у процесі дослідження проведено виміри силових показників в основних змагальних рухах висококваліфікованих армспортменів на етапі передзмагальної підготовки. В дослідженні прийняло участь 24 армспортсмена вищої кваліфікації у 3 вагових категоріях (до 80 кг, 80-100 кг, понад 100 кг) по 8 осіб у кожній. Показники вимірювали електротензодинамометром серії FBk польського виробництва з класом точності до 100 грамів, що був закріплений на спеціалізованому столі для армспорту за допомогою спеціально виготовленого блочного пристрою «Прибор ARM1».

\section{Результати дослідження}

Результати силових вимірів зазначених груп м'язів наведено у таблиці 1.

Порівняльний аналіз силових показників висококваліфікованих армспортсменів різних вагових категорій довів, що рукоборці вагою від 80 до 100 кг мали значно кращі силові можливості в порівнянні не тільки з ваговою групою до 80 кг, але й понад 100 кг. Так, силові можливості пальців рук в абсолютних показниках спортсменів другої групи (80-100 кг) були достовірно кращими в порівнянні з першою групою (до 80 кг). Сила згиначів пальців лівої та правої рук відносно малі $50,68 \pm 1,43$ кг проти 40,74 $\pm 0,72$ кг $(\mathrm{p}<0,001 ; \mathrm{t}=6,13)$ та 52,81 $\pm 0,9$ кг проти 41,85 $\pm 0,87$ кг $(p<0,001 ; t=8,77)$. При цьому, показники відносної сили

Таблиця 1

Середні силові показники у тестових вправах висококваліфікованих армспортсменів (абсолютні (кг), відносні (кг/кг))

\begin{tabular}{|c|c|c|c|c|c|c|c|c|c|}
\hline \multirow[b]{2}{*}{ Вагові групи } & \multirow[b]{2}{*}{ Показники } & \multicolumn{2}{|c|}{ Згинання пальців } & \multicolumn{2}{|c|}{ Натяжка молотком } & \multicolumn{2}{|c|}{ Гак } & \multicolumn{2}{|c|}{ Згинання кисті } \\
\hline & & ліва рука & $\begin{array}{c}\text { права } \\
\text { рука }\end{array}$ & ліва рука & $\begin{array}{c}\text { права } \\
\text { рука }\end{array}$ & ліва рука & $\begin{array}{c}\text { права } \\
\text { рука }\end{array}$ & ліва рука & $\begin{array}{c}\text { права } \\
\text { рука }\end{array}$ \\
\hline \multirow{2}{*}{ до 80 кг } & абсолютні & $\begin{array}{c}40,74 \pm \\
0,72\end{array}$ & $\begin{array}{c}41,85 \pm \\
0,87\end{array}$ & $\begin{array}{c}44,01 \pm \\
0,65\end{array}$ & $\begin{array}{c}44,95 \pm \\
0,57\end{array}$ & $\begin{array}{c}56,42 \pm \\
1,65\end{array}$ & $\begin{array}{c}61,01 \pm \\
1,32\end{array}$ & $\begin{array}{c}43,74 \pm \\
0,74\end{array}$ & $\begin{array}{c}46,54 \pm \\
0,40\end{array}$ \\
\hline & відносні & $\begin{array}{c}0,538 \pm \\
0,009\end{array}$ & $\begin{array}{c}0,551 \pm \\
0,010\end{array}$ & $\begin{array}{c}0,567 \pm \\
0,012\end{array}$ & $\begin{array}{c}0,592 \pm \\
0,009\end{array}$ & $\begin{array}{c}0,809 \pm \\
0,030\end{array}$ & $\begin{array}{c}0,860 \pm \\
0,034\end{array}$ & $\begin{array}{c}0,580 \pm \\
0,024\end{array}$ & $\begin{array}{c}0,622 \pm \\
0,027\end{array}$ \\
\hline \multirow{2}{*}{ 80-100 кг } & абсолютні & $\begin{array}{c}50,68 \pm \\
1,43\end{array}$ & $52,81 \pm 0,9$ & $\begin{array}{c}59,08 \pm \\
0,94\end{array}$ & $\begin{array}{c}61,83 \pm \\
1,47\end{array}$ & $\begin{array}{c}81,88 \pm \\
0,75\end{array}$ & $\begin{array}{c}85,00 \pm \\
1,10\end{array}$ & $\begin{array}{c}66,86 \pm \\
0,58\end{array}$ & $\begin{array}{c}70,63 \pm \\
0,79\end{array}$ \\
\hline & відносні & $\begin{array}{c}0,543 \pm \\
0,016\end{array}$ & $\begin{array}{c}0,566 \pm \\
0,011\end{array}$ & $\begin{array}{c}0,625 \pm \\
0,014\end{array}$ & $\begin{array}{c}0,663 \pm \\
0,017\end{array}$ & $\begin{array}{c}0,891 \pm \\
0,028\end{array}$ & $\begin{array}{c}0,905 \pm \\
0,030\end{array}$ & $\begin{array}{c}0,718 \pm \\
0,018\end{array}$ & $\begin{array}{c}0,761 \pm \\
0,034\end{array}$ \\
\hline \multirow{2}{*}{$\begin{array}{l}\text { понад } \\
100 \text { кг }\end{array}$} & абсолютні & $47,65 \pm 1,7$ & $\begin{array}{c}50,83 \pm \\
1,76 \\
\end{array}$ & $\begin{array}{c}54,67 \pm \\
0,44\end{array}$ & $\begin{array}{c}57,70 \pm \\
1,25\end{array}$ & $\begin{array}{c}72,45 \pm \\
1,51\end{array}$ & $\begin{array}{c}77,25 \pm \\
2,16\end{array}$ & $\begin{array}{c}57,38 \pm \\
1,84 \\
\end{array}$ & $\begin{array}{c}62,16 \pm \\
2,28 \\
\end{array}$ \\
\hline & відносні & $\begin{array}{c}0,405 \pm \\
0,015\end{array}$ & $\begin{array}{c}0,432 \pm \\
0,016\end{array}$ & $\begin{array}{c}0,458 \pm \\
0,022\end{array}$ & $\begin{array}{c}0,489 \pm \\
0,021\end{array}$ & $\begin{array}{c}0,613 \pm \\
0,031\end{array}$ & $\begin{array}{c}0,655 \pm \\
0,042\end{array}$ & $\begin{array}{c}0,475 \pm \\
0,018\end{array}$ & $\begin{array}{c}0,524 \pm \\
0,034\end{array}$ \\
\hline
\end{tabular}

Таблиця 2

Достовірні відмінності сили згиначів пальців висококваліфрікованих армспортсменів

\begin{tabular}{|c|c|c|c|c|}
\hline $\begin{array}{c}\text { № } \\
\text { 3/п }\end{array}$ & Вагова категорія & Показники & Ліва рука & Права рука \\
\hline \multirow{2}{*}{1} & Достовірність між 80 та 80-100 $(\mathrm{n}=8)$ & абсолютні & $\mathrm{p}<0,001 ; \mathrm{t}=6,13$ & $\mathrm{p}<0,001 ; \mathrm{t}=8,77$ \\
\cline { 3 - 5 } & \multirow{2}{*}{2} & відносні & $\mathrm{p}>0,05 ; \mathrm{t}=0,27$ & $\mathrm{p}>0,05 ; \mathrm{t}=1,006$ \\
\hline \multirow{2}{*}{3} & Достовірність між 80-100 та понад 100 $(\mathrm{n}=8)$ & абсолютні & $\mathrm{p}<0,01 ; \mathrm{t}=3,75$ & $\mathrm{p}<0,01 ; \mathrm{t}=4,58$ \\
\cline { 3 - 5 } & Достовірність між 80 та понад 100 $(\mathrm{n}=8)$ & відносні & $\mathrm{p}<0,001 ; \mathrm{t}=7,6$ & $\mathrm{p}<0,001 ; \mathrm{t}=6,62$ \\
\cline { 3 - 5 } & абсолютні & $\mathrm{p}>0,05 ; \mathrm{t}=1,36$ & $\mathrm{p}>0,05 ; \mathrm{t}=1,01$ \\
\hline
\end{tabular}




\section{СЛОБОЖАНСЬКИЙ НАУКОВО-СПОРТИВНИЙ ВІСНИК:}

\section{Матеріали XIX Міжнародної науково-практичної конференції «Фізична культура, спорт і здоров'я: стан, проблеми та перспективи»}

Таблиця 3 Достовірні відмінності сили у вправі натяжка молотком висококваліфікованих армспортсменів

\begin{tabular}{|l|l|l|l|l|}
\hline $\begin{array}{l}\text { № } \\
\text { 3/п }\end{array}$ & Вагова категорія & Показники & Ліва рука & Права рука \\
\hline \multirow{2}{*}{1} & Достовірність між 80 та 80-100 & абсолютні & $\mathrm{p}<0,001 ; \mathrm{t}=11,59$ & $\mathrm{p}<0,001 ; \mathrm{t}=10,55$ \\
\cline { 2 - 5 } & відносні & $\mathrm{p}<0,05 ; \mathrm{t}=3,22$ & $\mathrm{p}<0,01 ; \mathrm{t}=3,73$ \\
\hline \multirow{2}{*}{2} & Достовірність між 80-100 та понад 100 & абсолютні & $\mathrm{p}<0,001 ; \mathrm{t}=13,7$ & $\mathrm{p}<0,001 ; \mathrm{t}=9,3$ \\
\cline { 3 - 5 } & Відносні & $\mathrm{p}<0,01 ; \mathrm{t}=4,36$ & $\mathrm{p}<0,01 ; \mathrm{t}=4,25$ \\
\hline
\end{tabular}

пальців рук як лівої та правої рук мали не достовірну різ-

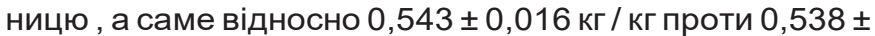
0,009 кг / кг (p > 0,05; $\mathrm{t}=0,27) ; 0,566 \pm 0,011$ кг / кг проти $0,551 \pm 0,010$ кг / кг (p>0,05; $\mathrm{t}=1,006)$ (табл. 1, 2).

Порівняння абсолютних силових показників спортсменів вагових категорій до 80 кг та понад 100 кг свідчить про те, що сила пальців важковаговиків, як і очікувалося, була достовірно вищою (ліва рука - $p<0,01$; $t=3,75$; права рука $-\mathrm{p}<0,01 ; \mathrm{t}=4,58)$. Стосовно відносних силових можливостей відмічається, що показники спортсменів легкої вагової категорії суттєво вищі, а саме: лівої руки $-0,538 \pm 0,009$ кг / кг проти 0,405 \pm 0,015 кг/ кг $(p<0,001$; $\mathrm{t}=7,6)$; правої руки - 0,551 \pm 0,010 кг / кг проти 0,432 $0,016$ кг / кг ( $p<0,001 ; t=6,62)$. Аналогічна динаміка силових можливостей згиначів пальців рук зберігається в армспортсменів вагових категорій 80-100 кг та понад 100 кг (табл. 2) з високими показниками достовірності $\mathrm{t}=6,27$ та 7,01 при $\mathrm{p}<0,001$.

Порівняння показників абсолютної сили пальців лівої та правої рук між спортсменами вагових категорії 80100 кг та понад 100 кг дозволяє стверджувати, що рукоборці більш легкої категорії мають кращі силові показники від важковаговиків, але різниця в обох випадках не достовірна. А саме, дані лівої руки 50,68ะ1,43 кг проти

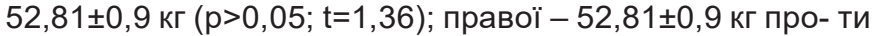
$50,83 \pm 1,76$ кг $(p>0,05 ; t=1,01)$. У той же час, відносні силові можливості рукоборців другої групи (80-100 кг) були суттєво високими: лівої руки - 0,543 \pm 0,016 кг / кг проти 0,566 $\pm 0,011$ кг / кг (p<0,001; $\mathrm{t}=6,27)$; правої $0,566 \pm 0,011$ кг / кг проти 0,432 $\pm 0,016$ кг / кг $(\mathrm{p}<0,001 ; \mathrm{t}$ $=7,01)$ (табл. 2).

Показники силових можливостей спортсменів у вправі натяжка молотком свідчать, що представники другої групи (80-100 кг) як в абсолютних, так й у відносних показниках сили досягають значно високих результатів у порівнянні з досягненнями спортсменів першої (до 80 кг) та третьої (понад 100 кг) груп (табл. 3).

Так, різниця абсолютної сили між першою та другою групами лівої руки склала 25,5 \% (p < 0,001; $\mathrm{t}=11,59)$, правої руки - 27,3 \% ( $<<0,001 ; t=10,55)$. У відносних показниках сили різниця була меншою, але також достовірною та склала відповідно 9,28 \% $(p<0,05 ; t=3,22)$ та $10,71 \%$ ( $<<0,01 ; t=3,73)$. Абсолютні силові можливості спортсменів другої групи у цій вправі були значно вищими ніж представників більшої вагової категорії (понад 100 кг): лівої руки - 7,46 \% ( $<0,01 ; t=4,25)$, правої руки $-6,67 \%$ ( $>$ > 0,05; $t=2,14)$. А різниця відносних силових показників дорівнювала відповідно - 26,6 \% $(\mathrm{p}<0,05 ; \mathrm{t}=$ $2,58)$ та $26,24 \%(p<0,001 ; t=6,44)$.

Порівняльний аналіз результатів силової вправи натяжка молотком між армспортсменами першої та третьої груп (до 80 кг та понад 100 кг) показав, що в абсолютних показниках сили обох рук важковаговики були сильнішими, відповідно на 24,2 та 28,36 кг ( $<<0,001 ; \mathrm{t}=13,7$ i 9,3). Стосовно відносних показників сили, навпаки легковаговики (до 80 кг) мали достовірно високі результати: лівою рукою на 23,79 \% ( $p<0,01 ; t=4,36)$, правою - на 21,06 \% $(\mathrm{p}<0,01 ; \mathrm{t}=4,48)$ (табл. 3$)$.

У силовій вправі гак друга вагова група за абсолютними показниками сили обох рук була достовірно кращою від обох інших. Так, у порівнянні з першою групою показники лівої руки більші на 45,12 \% ( $<0,001 ; t=13,99)$, правою - на 39,32 \% ( $<$ 0,001; $t=13,94)$. Спортсмени третьої групи показали гірші результати: лівою рукою на $13,1 \%$ менше $(p<0,001 ; t=7,16)$, правою - на 10,03 $\%(p<0,001 ; t=6,41)$ (табл. 4).

Абсолютні результати важковаговиків (понад 100 кг) у цієї вправі природно були кращими ніж показники 3 легкою вагою (до 80 кг): лівої руки на 28,41 \% ( $<$ 0,001; $\mathrm{t}=5,59)$, правої - на 26,61\% $(\mathrm{p}<0,05 ; \mathrm{t}=3,2)$.

За даними відносної сили результати другої групи армспортсменів також були вищими. Але різниця між показниками другої та першою груп була не достовірною, а саме: ліва рука на 10,13 \% ( $>$ > 0,05; $t=2,00)$, права - на $5,2 \%$ ( $>$ > 0,05; $t=0,99)$. Різниця між показниками другої та третьої груп у цій вправі була значною та склала лівою

Таблиця 4

Достовірні відмінності сили у вправі гак висококваліфікованих армспортсменів

\begin{tabular}{|c|c|c|c|c|}
\hline $\begin{array}{l}\text { № } \\
\text { 3/ח }\end{array}$ & Вагова категорія & Показники & Ліва рука & Права рука \\
\hline \multirow{2}{*}{1} & \multirow{2}{*}{ Достовірність між 80 та 80-100 } & абсолютні & $p<0,001 ; t=13,99$ & $p<0,001 ; t=13,94$ \\
\hline & & відносні & $p>0,05 ; t=2$ & $p>0,05 ; t=0,99$ \\
\hline \multirow{2}{*}{2} & \multirow{2}{*}{ Достовірність між 80-100 та понад 100} & абсолютні & $p<0,001 ; t=7,16$ & $p<0,001 ; t=6,41$ \\
\hline & & відносні & $p<0,01 ; t=4,52$ & $p<0,01 ; t=3,79$ \\
\hline \multirow{2}{*}{3} & \multirow{2}{*}{ Достовірність між 80 та понад 100} & абсолютні & $p<0,001 ; t=5,59$ & $p<0,05 ; t=3,2$ \\
\hline & & відносні & $p<0,001 ; t=6,62$ & $p<0,01 ; t=3,79$ \\
\hline
\end{tabular}


СЛОБОЖАНСЬКИЙ НАУКОВО-СПОРТИВНИЙ ВІСНИК:

Матеріали XIX Міжнародної науково-практичної конференції «Фізична культура, спорт і здоров'я: стан, проблеми та

Таблиця 5

Достовірні відмінності сили у вправі згинання кисті висококваліфікованих армспортсменів

\begin{tabular}{|c|c|c|c|c|}
\hline $\begin{array}{l}\text { № } \\
\text { 3/ח }\end{array}$ & Вагова категорія & Показники & Ліва рука & Права рука \\
\hline \multirow{2}{*}{1} & \multirow{2}{*}{ Достовірність між 80 та 80-100 } & абсолютні & $p<0,001 ; t=24,60$ & $p<0,001 ; t=27,06$ \\
\hline & & відносні & $p<0,01 ; t=4,61$ & $p<0,05 ; t=3,23$ \\
\hline \multirow{2}{*}{2} & \multirow{2}{*}{ Достовірність між 80-100 та понад 100} & абсолютні & $p<0,001 ; t=6,88$ & $p<0,001 ; t=6,76$ \\
\hline & & відносні & $p<0,01 ; t=3,50$ & $p>0,05 ; t=2,28$ \\
\hline \multirow{2}{*}{3} & \multirow{2}{*}{ Достовірність між 80 та понад 100} & абсолютні & $p<0,01 ; t=4,96$ & $p<0,01 ; t=3,51$ \\
\hline & & відносні & $p<0,01 ; t=4,19$ & $p<0,01 ; t=4,93$ \\
\hline
\end{tabular}

рукою $45,35 \%(p<0,01 ; t=4,52)$, правою $-38,16 \%(p$ $<0,01 ; \mathrm{t}=3,79)$. Результати спортсменів третьої групи за показниками відносних силових можливостей були гижчими ніж легковаговиків (до 80 кг): лівою рукою 28,41\% (р $<0,001 ; t=6,62)$, правою $-26,61 \%(p<0,01 ; t=3,79)$.

Аналізрезультатіввиконаннясиловоївправизгинання кисті рук показав, що рукоборці другої групи як в абсолютних, так й у відносних силових показниках обох рук були суттєво кращими по відношенню до результатів спортсменів другої та третьої груп. Порівняльний аналіз довів, що представники вагової категорії 80-100 кг відрізнялися більшою силою від показників легковаговиків (до 80 кг): лівої руки на $51,71 \%(p<0,001 ; t=24,6)$, правої $-51,76 \%$ $(p<0,001 ; t=27,06)$. Абсолютний показник сили кисті рук спортсменів-важковаговиків у порівнянні з досягненнями представників першої групи був природно вищим. Так, лівої руки на $31,18 \%(p<0,01 ; t=4,96)$, правої - на 33,56 \% $(p<0,01 ; t=3,51)$ (табл. 5).

Кистьова динамометрія армспортсменів першої групи була значно вищою у порівнянні з результатами третьої групи: кисті лівої руки на 22,1\% ( $<<0,01 ; t=4,19)$, а правої - на $18,7 \%(p<0,01 ; t=4,93)$. Показники відносних силових можливостей кистей рук рукоборців другої групи достовірно вищі. Так, у порівнянні з даними представників першої групи - кисть лівої руки на 23,79 \% ( $<<0,01 ; \mathrm{t}=$
4,61), правої - на 22,34 \% ( $<<0,05 ; \mathrm{t}=3,23)$. Результати кисті лівої руки третьої групи на 51,16 \% краще $(\mathrm{p}<0,01$; $\mathrm{t}=3,50)$, правої.

\section{Висновки /Дискусія}

1. Порівняльний аналіз усіх досліджених показників силових можливостей висококваліфікованих армспортсменів дозволив встановити, що найбільш високі результати були показані в силових вправах гак і згинанні кисті.

2. Можна стверджувати, що силові вправи дозволяють достатньо чітко визначити рівень силової підготовленості армспортсменів, а сама це є головним показником результативності висококваліфікованих армспортсменів.

3. Отримані результати свідчать про те, що армспортсмени з гіршими силовими показниками досягають результатів за рахунок включення до виконання силових вправ більшої кількості м'язових груп i, навпаки, більш високі силові показники досягаються за рахунок виконання силових вправ певною м'язовою групою.

Подальші дослідження будуть спрямовані на застосування силової методики підготовки спортсменів вищої кваліфрікації. Для оцінювання методики планується застосування спеціального інноваційного обладнання MAZURENKO EQUPMENT.

Конфллікт інтересів. Автори заявляють, що немає конфлікту інтересів, який може сприйматися таким, що може нанести шкоду неупередженості статті. Джерела фінансування. Ця стаття не отримала фінансової підтримки від державної, громадської або комерційної організації.

\section{Список посилань}

1. Безкоровайний, Д. О. (2008). "Розвиток сили згиначів передпліччя та згиначів кисті у школярів 8-17 років, які займаються армспортом". Слобожанський науково-спортивний вісник, 4, 9-12.

2. Безкоровайний, Д. О. (2010). Навчання техніці боротьби на руках: практичні рекомендації для занять армспортом. ХНАМГ, Харків. 3. Безкоровайний, Д. О. (2013). "Базова система тренування та система безпосередньої підготовки до змагань в армспорті". Пе-

дагогіка, психологія та медико-біологічні проблеми фрізичного виховання і спорту : зб. наук. праць за ред. профр. С. Єрмакова, 1, 13-16.

4. Безкоровайний, Д.О.(2013) Оптимізація розвитку сили та статичної витривалості у 8-17-річних юнаків в армспорті (моногра- фрія). ХНУМГ, Харків.

5. Бельский, И. В. (2003). Системы эффрективной тренировки: армрестлинг, бодибилдинг, бенчпресс, пауэрлифртинг. Вида-Н, Минск.

6. Водлозеров, В. Е., \& Ефрименко, А. М. (2003). "Исследование эфффективности системы тренажеров локально направленного действия для тренировки рук". Матеріали VI Міжнародної науково-практичної конфреренції "Наука і освіта 2003", (30), 51-52.

7. Галашко, А. И., \& Галашко, Н. И. (2008). "Сравнительная оценка антропометрического развития спортсменов силовых видов спорта". Теорія та методика фізичного виховання, (4), 13-17.

8. Живора, П. В., \& Рахманов, А. И. (2001). Армспорт: учеб. пособие для студ. высших пед. учебных заведений. Изд. центр «Академия», Москва.

9. Звягінцева, І. М. (2009). Силова та фрізична підготовка. Армспорт : методичні вказівки. ХНАМГ, Харків.

10. Камаєв, О. І., \& Безкоровайний, Д. О. (2013). "Влив експериментальної програми тренування з армспорту на силові показники основних м'язових груп 16-17-річних рукоборців" Педагогіка, психологія та медико-біологічні проблеми фрізичного виховання $і$ спорту : зб. наук. праць за ред. С. С. Єрмакова, (1), 34-37.

11. Камаев, О. И. (2000). Теоретические и методические основы оптимизации системы многолетней подготовки юных лыжников- 


\section{СЛОБОЖАНСЬКИЙ НАУКОВО-СПОРТИВНИЙ ВІСНИК:}

\section{Матеріали XIX Міжнародної науково-практичної конференції «Фізична культура, спорт і здоров'я: стан, проблеми та перспективи»}

гонщиков. (Авторефр.дисс. Ә-ра наук по фриз. восп). Харьков, Украина

12. Клочко, В. М. \& Безкоровайний, Д. О. (2005). Спортивні єдиноборства. Армспорт. Техніка, тактика і методика навчання : конспект лекцій для вивчення модулю "Фізичне виховання". ХНАМГ, Харків.

13. Комаревич, О. Є., Безкоровайний, Д. О., Красов, В. П. \& Звягінцева, І. М. (2018). Організація суддівства змагань з армспорту : навчальний посібник. НУВГП, Рівне.

14. Подрігало, Л. В., Галашко, О. І., Галашко, М. І., \& Городиський, М. І. (2008). "Біомеханічні особливості армспорту". Слобожанський науково-спортивний вісник, (4), 167-174.

15. Платонов, В. Н. (2015). Система подготовки спортсменов в олимпийском спорте. Общая теория и ее практические приложения: учебник. Олимпийская л-ра, Киев.

16. Усанов, Е. И., \& Чуглина, Л. В. (2010). Армрестлинг - борьба на руках : учеб. пособие. РУДН, Москва.

Стаття надійшла до редакції: 11.11.2019 p.

Опубліковано: 30.12.2019 p.

Аннотация. Мазуренко И. А. Анализ силовых показателей высококвалифицированных армспортсменов на этапе предсоревновательной подготовки. Цель работы - анализ показателей силовой подготовки основных соревновательных движений армспортсменов высшей квалиффикации на этапе предсоревновательной подготовки. Задачи работы: анализ тренировочного процесса при подготовке к соревнованиям по армрестлингу; выявление оптимальных силовых показателей при подготовке к соревнованиям по армрестлингу; определение методики подготовки к главным соревнованиям по армрестлингу. Методы исследования: теоретический анализ и обобщение данных научно-методической литературы и методики тренировочного процесса высококвалифицированных армспортсменов при подготовке к основным соревнованиям, педагогический эксперимент (кистевой динамометрии, тензодинамометрия). Материал: в процессе исследования проведены замеры силовых показателей в основных соревновательных движениях высококвалифицированных 24 армспортсменов 3 весовых категориях (до 80 кг, $80-100$ кг, свыше 100 кг) по 8 человек в каждой на этапе предсоревновательной подготовки. Показатели измеряли електротензодинамометром серии FBk польского производства с классом точности до 100 граммов, с помощью специально изготовленного блочного устройства «Прибор ARM1». Результаты в результате анализа, силовые показатели 4 соревновательных движений (саибании пальцев, натяжка молотом, крюк, сәибании кисти) высококвалифицированных армспортсменов были достоверно высокими в весовой категории 80100 ке. Причем показатель силы крюке правой руки был самым высоким именно в этой весовой группе, а самый низкий пока- затель зафиксирован в весовой группе до 80 ка в сгибании пальцев. Выводы: сравнительный анализ всех исследованных показателей силовых возможностей высококвалифицированных армспортсменов позволил установить, что наиболее высокие результаты были показаны в силовых упражнениях крюк и саибании кисти; можно утверждать, что силовые упражнения позволяют достаточно четко определить уровень силовой подготовленности армспортсменов, а сама это является главным показателем результатив- ности высококвалифицированных армспортсменов; полученные результаты свидетельствуют о том, что армспортсмены с худиими силовыми показателями достигают результатов за счет включения в выполнение силовых упражнений больщего количества мышечных групп и, наоборот, более высокие силовые показатели достигаются за счет выполнения силовых упражнений определенной мышечной группой.

Ключевые слова: армрестлинг, силовые показатели, соревнования.

Abstract. Mazurenko I. Analysis of strength indicators of highly qualified armwrestlers at the stage of pre-competition training. The purpose of the work is to analyze the strength indicators of the main competitive movements of armwrestlers of the highest qualification at the stage of pre-competition preparation. Objectives: analysis of the training process in preparation for arm wrestling competitions; identification of optimal strength indicators in preparation for arm wrestling competitions; determination of the methodology for preparing for the main arm wrestling competitions. Research methods: theoretical analysis and synthesis of scientific and methodological literature and the training process of highly qualified armwrestlers in preparation for the main competitions, a pedagogical experiment (hand dynamometry, tensodynamometry). Material: in the course of the study, power indicators were measured in the main competitive movements of highly qualified 24 armwrestlers in 3 weight categories (up to $80 \mathrm{~kg}, 80-100 \mathrm{~kg}$, over $100 \mathrm{~kg}$ ), 8 people each at the stage of pre-competition training. The indicators were measured by a Polish-made FBk series electrodynamics dynamometer with an accuracy class of up to 100 grams, using a specially made block device "ARM1 Device". The results of the analysis, strength indicators of 4 competitive movements (bending fingers, hammer stretching, hook, bending of the hand) of highly qualified armwrestlers were significantly high in the weight category of 80-100 kg. Moreover, the indicator of the strength of the hook of the right hand was the highest in this weight group, and the lowest indicator was recorded in the weight group of up to $80 \mathrm{~kg}$ in flexion of the fingers. Conclusions: a comparative analysis of all the investigated indicators of power capabilities of highly qualified armwrestlers allowed us to establish that the highest results were shown in power exercises hook and flexion of the hand; it can be argued that strength exercises make it possible to clearly determine the level of strength preparedness of armwrestlers, and this itself is the main indicator of the effectiveness of highly qualified armwrestlers; the results obtained indicate that armwrestlers with worse strength indicators achieve results by including more muscle groups in the performance of strength exercises and, conversely, higher strength indicators are achieved by performing strength exercises with a specific muscle group.

Keywords: armwrestling, power indicators, competitions.

\section{References}

1. Bezkorovainyi, D. O. (2008). "Rozvytok zgynachiv peredplicha ta zgynachiv kysti u shcolyariv 8-17 rokiv, yaki zaymautsya armsportom".

Slobozanskiy naukovo-sportyvyi visnyk, 4, 9-12. (in Ukr.).

2. Bezkorovainyi, D. O. (2010). Navchannya tehnyci borotby na rukah : praktychni rekomendactii dlya zanyat armsportom. HNAMG, Harkiv.(in Ukr).

3. Bezkorovainyi, D. O. (2013). "Bazova systema trenuvan ta systema bezposeregn'oyi pidgotovky do zmagan $v$ armsporti". Pedagogika, psyhologiyaя ta medyko-biologichni problem fizychnogo vyhovannya i sportu :zb. nauk. pract za red. prof. S. Yermakova, $1,13-$ 16.(in Ukr).

4. Bezkorovainyi, D. O. (2013) Optymizachiya rozvytku syly ta statychnoyi vytryvalosti u 8-17-richnyh yunakiv v armsporti (monografiya). HNUMG, Harkiv.(in Ukr)

5. Belskiy, I. V. (2003). Sistemy efektivnoy treniroki: armrestling, bodibilfing, benchpress, pauerlinting. Vida-N, Minsk.(in Russ).

6. Vodlozerov, V. E., \& Yefimenko, A. M. (2003). "Issledovaniye effektivnosti sistemy trenzherov lokalno napravlenogo deystviyz dlya trenirovki ruk". Materialy VI Mizhnarodnoyi naukovo-praktychnoyi konferenchii "Nauka I osvita 2003", (30), 51-52.(in Russ).

7. Galashko, A. I., \& Galashko, N. I. (2008). «Sravnitelnaya ostenka antropometricheskogo razvitiya sportcmenov silovyh vidov sporta». Teoriya i metodyka fizychnogo vyhovannya, (4), 13-17.(in Russ).

8. Zhyvora, P. V., \& Rahmanov, A. I. (2001). Armsport: ucheb. posobiye dlya stud. vysshyh ped. uchebnyh zavedeniy. Izd. tsentr "Akademiya", Moskva.(in Russ).

9. Zvyagintseva, I. M. (2009). Sylova ta fizychna pidgotovka. Armsport : metodychni vkazivky. HNAMG, Harkiv.(in Ukr). 


\section{СЛОБОЖАНСЬКИЙ НАУКОВО-СПОРТИВНИЙ ВІСНИК: \\ Матеріали XIX Міжнародної науково-практичної конференції «Фізична культура, спорт і здоров'я: стан, проблеми та}

10. Kamayev, O. I., \& Bezkorovainyi, D. O. (2013). "Vplyv eksperymentalnoyi program trenuvannya z armsportu na sylovi pokaznyki osnovnyh vyazovyh 16-17-richnyh rukobortsiv" Pedagogika,psyhologiyaя ta medyko-biologichni problem fizychnogo vyhovannya $i$ sportu :zb. nauk. pract za red. prof. S. Yermakova, (1), 34-37.(in Ukr).

11. Kamayev, O. I. (2000). Teoretycheskiye i metodicheskiye osnovy optimizatsii sistemy mnogoleyney podgotovki yunyh lyzhnikovgonshikov. (Avtoref. dys. ... d-ra. nauk po fiz. voap. i sportu). Harkov, Ukraina.(in Russ).

12. Klochko, V. M. \& Bezkorovainyi, D. O. (2005). Sportivnyye yedinoborstva. Armsport. Tehnika, taktyka, metodyka navchannya : konspekt lektsiy dlya vyvchennya modulyu "Fizychne vyhovannyz". HNAMG, Harkiv.(in Ukr).

13. Komarevich, O. Y., Bezkorovainyi, D. O., Krasov, V. P. \& Zvyagintseva, I. M. (2018). Organizatsiya suddivstva zmagan z armsportu : navchalnyy posibnyk. NUVGP, Rivne.(inUkr).

14. Podrygalo, L. V., Galashko, O. I., Galashko, M. I., \& Gorodynskiy, M. I. (2008). "Biomehanichni osoblyvosti armsportu". Slobozanskiy naukovo-sportyvyi visnyk, (4), 167-174.(in Ukr).

15. Platonov, V. N. (2015). Sistema podgotovki sportsmenov v olimpijskom sporte. Obshhaja teorija i ee prakticheskie prilozhenija : uchebnik [dlja trenerov] : 2 kn. Olimp. lit., Kiev.(in Russ).

16. Usanov, E. I., \& Chuglina, L. V. (2010). Armrestling - bor'ba na rukah : ucheb. posobiye. RUDN, Moskva.(in Russ).

Received: 11.11.2019

Published: 30.12 .2019 .

\section{Відомості про авторів / Information about the Authors}

Мазуренко Ігор Олександрович: аспірант; Харківська державна академія фрізичної культури: вул. Клочківська, 99, м. Харків, 61058.

Мазуренко Игорь Александрович: аспирант; Харьковская государственная академия физической культуры: ул. Клочковская, 99, Харьков, 61058, Украина.

Igor Mazurenko: Graduate Student; Kharkov State Academy of Physical Culture: Klochkovskaya st., 99, Kharkov, 61058, Ukraine ORCID.ORG/https://orcid.org/0000-0003-2827-7258 E-

mail: bezkor@ua.fm 